\title{
EXERGY ANALYSIS OF A BRAYTON CYCLE WITH VARIABLE PHYSICAL PROPERTIES AND VARIABLE COMPOSITION OF WORKING SUBSTANCE
}

\author{
Marija Živić, Antun Galović, Jurij Avsec, Mario Holik
}

Original scientific paper

The exergy analysis of a Brayton cycle is performed in the paper. The four input variables: the ratio of the compressor exit and inlet pressures, the ratio of inlet temperature of gases in turbine and inlet temperature of air in compressor and the isentropic efficiencies of the compressor and turbine are analysed. The temperature ratio is varied in a way that the compressor inlet temperature of air is maintained constant, while the turbine inlet temperature of flue gases is varied from 900 to $1200^{\circ} \mathrm{C}$. In the combustion chamber methane is completely combusted with excess air ratio which is determined by the temperature of flue gases at the turbine inlet. The analysis further includes variability of the molar heat capacities of air and flue gases with temperature and variability of their heat capacity ratios. The exergy destruction in turbine, compressor and combustion chamber and also total exergy efficiency of the cycle are considered in the analysis.

Keywords: Brayton cycle, variable physical properties, variable composition of working substance, maximum work output, maximum thermal efficiency

\section{Eksergijska analiza Braytonovog ciklusa s promjenjivim fizikalnim svojstvima i promjenjivim sastavom radne tvari}

Izvorni znanstveni članak

U radu je provedena eksergijska analiza Braytonovog ciklusa. Četiri ulazne varijable, omjer tlakova na izlazu i ulazu u kompresor, omjer temperature na ulazu u turbinu i temperature na ulazu u kompresor, te izentropski stupnjevi djelovanja kompresora i turbine su uzeti u analizu. Omjer temperatura je variran tako da je temperatura zraka na ulazu u kompresor držana konstantnom, a temperatura dimnih plinova na ulazu u turbinu je varirana od $900{ }^{\circ} \mathrm{C}$ do $1200{ }^{\circ} \mathrm{C}$. U komori za izgaranje potpuno izgara metan s pretičkom zraka koji je određen temperaturom dimnih plinova na ulazu u turbinu. Analiza nadalje uključuje promjenjivost molarnih toplinskih kapaciteta zraka i dimnih plinova s temperaturom i promjenjivost njihovih izentropskih eksponenata. Eksergijska destrukcija u komori za izgaranje, turbini i kompresoru kao i ukupna eksergijska efikasnost su uzete u analizu.

Ključne riječi: Braytonov ciklus, promjenjiva fizikalna svojstva, promjenjiv sastav radne tvari, maksimalni neto rad, maksimalni stupanj djelovanja

\section{Introduction}

A gas turbine operates on a Brayton cycle. The gas turbine is known to feature low capital cost to power ratio, high flexibility, high reliability without complexity, short delivery time, early commissioning and commercial operation and fast starting-accelerating [1]. It is further recognized for its better environmental performance, manifested in the curbing of air pollution and reducing greenhouse gases [2]. Many optimizations of Brayton cycle have been carried out. The maximum power output or the maximum thermal efficiency has been mostly used as optimization criteria. Criterion of maximum efficiency is used most frequently in power plants, in which the fuel consumption is important, while the criterion of maximum work output is significant in aircrafts in which the propulsion is of great importance. Both fuel consumption and thrust gain may be equally important, for example, for ship propulsion systems, therefore, in this case, both the maximum power and the maximum thermal efficiency criteria have to be considered in the design [3]. In detailed analysis [4], for thermodynamic optimization of a Brayton cycle, authors proposed two goal functions. The first maximizes the sum of the network per cycle and thermal efficiency while the second the network per cycle and exergy efficiency. In recent paper [5], Haseli conducted an analysis of the regenerative open Brayton cycle and optimisation on the basis of maximisation of the work output, maximisation of the thermal efficiency and minimisation of the entropy generation.

Most optimizations were performed using the airstandard model with constant physical properties of working substance. In this work, the maximum thermal efficiency, maximum work output and total exergy efficiency of the Brayton cycle were obtained using a model with variable physical properties and variable composition of working substance. This model better describes the process in the gas turbine engine, but it is not general. The model is valid for the particular fuel and for the chosen temperature of working substance.

\section{Mathematical model \\ 2.1 Energy analysis of the Brayton cycle}

In a Brayton cycle, air at ambient pressure and temperature is drawn into the compressor, where its temperature and pressure are raised. The high pressure air enters the combustion chamber, where the fuel is burned at constant pressure. The given high-temperature gases then enters the turbine, where they expand to the atmospheric pressure while producing power. The exhaust gases leaving the turbine are thrown out. Schematic representation of an open Brayton cycle is shown in Fig. 1a and its qualitative $T-s$ diagram in Fig. 1b. Irreversible adiabatic process in the compressor is represented by the line between points 1 and $2^{*}$, combustion by the line from $2^{*}$ to 3 and irreversible adiabatic expansion in the turbine by the line from 3 to $4^{*}$. Auxiliary lines from point 1 to 2and from 3 to 4 represent ideal (isentropic) processes in the compressor and turbine, respectively. In the combustion chamber methane $\mathrm{CH}_{4}$ is completely combusted. The air at the inlet of compressor (state 1) is at ambient pressure and temperature $\left(p_{0}=101325 \mathrm{~Pa}, T_{0}\right.$ $=298,15 \mathrm{~K}$ ). 


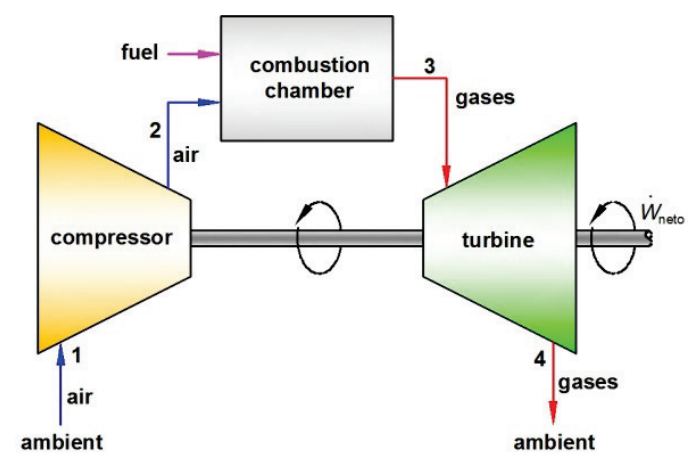

Figure 1a Shematic representation of an open Brayton cycle

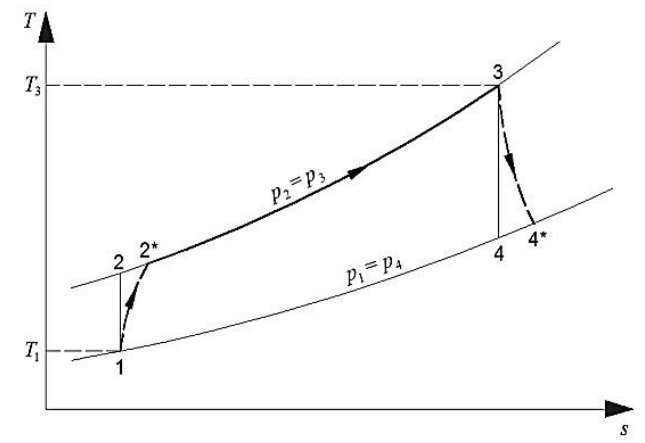

Figure 1b Qualitative $T-s$ diagram of an open Brayton cycle

\subsubsection{Work output}

The work output per cycle expressed per unit of the amount of fuel is given by the following equation

$$
\begin{aligned}
& w_{\text {net }}=w_{\text {turb }}-\left|w_{\text {comp }}\right| \\
& w_{\text {net }}=n_{\mathrm{fg}}\left[C_{\mathrm{m} p, \mathrm{fg}}\right]_{\vartheta_{4}^{*}}^{\vartheta_{3}}\left(T_{3}-T_{4}^{*}\right)-n_{\text {air }}\left[C_{\mathrm{m} p, \text { air }}\right]_{\vartheta_{1}}^{\vartheta_{2}^{*}}\left(T_{2}^{*}-T_{1}\right)
\end{aligned}
$$

Where: $w_{\text {net }}$ is the network output; $w_{\text {turb }}$ is the work output of the turbine; $w_{\text {comp }}$ is the work output of the compressor, $\left[C_{\mathrm{m} p, \mathrm{fg}}\right]_{\vartheta_{4}^{*}}^{\vartheta_{3}}$ is the mean molar heat capacity of flue gases in the given temperature interval; $\left[C_{\mathrm{m} p \text {,air }}\right]_{\vartheta_{1}}^{\vartheta_{2}^{*}}$ is the mean molar heat capacity of air; $n_{\mathrm{fg}}$ is the amount of flue gases per kilomol of fuel; $n_{\text {air }}$ is the amount of air per kilomol of fuel.

By using expressions for the isentropic efficiencies of compressor and turbine

$\eta_{\text {comp }}=\frac{\left[C_{\text {mp,air }}\right]_{\vartheta_{1}}^{\vartheta_{2}}\left(T_{2}-T_{1}\right)}{\left[C_{\mathrm{m} p, \text { air }}\right]_{\vartheta_{1}}^{\vartheta_{2}^{*}}\left(T_{2}^{*}-T_{1}\right)}$ $\eta_{\text {turb }}=\frac{\left[C_{\mathrm{m} p, \mathrm{fg}}\right]_{\vartheta_{3}}^{\vartheta_{4}^{*}}\left(T_{4}^{*}-T_{3}\right)}{\left[C_{\mathrm{m} p, \mathrm{fg}}\right]_{\vartheta_{3}}^{\vartheta_{4}}\left(T_{4}-T_{3}\right)}$

the work output can be written in dimensionless form

$$
\begin{aligned}
& w=\frac{w_{\text {net }}}{T_{1} n_{\text {air }}\left[C_{\mathrm{m} p, \text { air }}\right]_{\vartheta_{1}}^{\vartheta_{2}^{*}}} \\
& w=\frac{n_{\mathrm{fg}}\left[C_{\mathrm{m} p, \mathrm{fg}}\right]_{\vartheta_{3}}^{\vartheta_{4}^{*}} \eta_{\mathrm{turb}} r_{\mathrm{T}}}{n_{\text {air }}\left[C_{\mathrm{m} p, \text { air }}\right]_{\vartheta_{1}}^{\vartheta_{2}^{*}}}\left(1-\left(\frac{1}{r_{p}}\right)^{\frac{\kappa_{\text {turb }}-1}{\kappa_{\text {turb }}}}\right)+\frac{1-\left(r_{p}\right)^{\frac{\kappa_{\text {comp }}-1}{\kappa_{\text {comp }}}}}{\eta_{\text {comp }}}
\end{aligned}
$$

Where: $\kappa_{\text {comp }}$ is the heat capacity ratio of the air in the compressor; $\kappa_{\text {turb }}$ is the heat capacity ratio of the flue gases in the turbine; $r_{p}=p_{2} / p_{1}$ is the pressure ratio; $r_{T}=T_{3} / T_{1}$ is the temperature ratio; $\eta_{\text {turb }}$ is the isentropic efficiency of the turbine; $\eta_{\text {comp }}$ is the isentropic efficiency of the compressor.

For the given values of $\eta_{\text {comp }}$ and $\eta_{\text {turb, the }}$ temperatures $T_{2}^{*}$ and $T_{4}^{*}$ are obtained from the following equations

$$
\begin{gathered}
T_{2}^{*}=T_{1}+\frac{\left[C_{\mathrm{m} p, \text { air }}\right]_{\vartheta_{1}}^{\vartheta_{2}}\left(T_{2}-T_{1}\right)}{\eta_{\text {comp }}\left[C_{\mathrm{m} p, \text { air }}\right]_{\vartheta_{1}}^{\vartheta_{2}^{*}}} \\
T_{4}^{*}=T_{3}-\eta_{\text {turb }} \frac{\left[C_{\mathrm{m} p, \mathrm{fg}}\right]_{\vartheta_{3}}^{\vartheta_{4}}\left(T_{4}-T_{3}\right)}{\left[C_{\mathrm{m} p, \mathrm{fg}}\right]_{\vartheta_{3}}^{\vartheta_{4}^{*}}}
\end{gathered}
$$

In the Eq. (6), the values of pressure $p_{1}$ and temperature $T_{1}$ at the compressor inlet and the temperature ratio $r_{T}=T_{3} / T_{1}$ should be given.

The amount of flue gasses $n_{\mathrm{fg}}$ and the amount of air $n_{\text {air }}$ are obtained from the stoichiometric equation of the complete combustion of methane $\mathrm{CH}_{4}$.

The temperature of flue gases at the inlet of turbine is determined by the air excess ratio during complete combustion in the combustion chamber. In this work, the temperature of flue gases $\vartheta_{3}$ is varied from 900 to 1200 ${ }^{\circ} \mathrm{C}$ and the excess air ratio is obtained from the Eq. (9).

$$
\lambda=\frac{H_{\mathrm{ml}}\left(0^{\circ} \mathrm{C}\right)-\vartheta_{3}\left(n_{\mathrm{CO}_{2}}\left[C_{\mathrm{m} p \mathrm{CO}_{2}}\right]_{0}^{\vartheta_{3}}+n_{\mathrm{H}_{2} \mathrm{O}}\left[C_{\mathrm{m} p \mathrm{H}_{2} \mathrm{O}}\right]_{0}^{\vartheta_{3}}-O_{\mathrm{min}}\left[C_{\mathrm{m} p \mathrm{O}_{2}}\right]_{0}^{\vartheta_{3}}\right)}{O_{\min }\left[C_{\mathrm{m} p \mathrm{O}_{2}}\right]_{0}^{\vartheta_{3}} \vartheta_{3}-n_{\text {air_min }}\left[C_{\mathrm{m} p, \text { air }}\right]_{0}^{\vartheta_{2}^{*}} \vartheta_{2}^{*}+0,79 n_{\text {air_min }}\left[C_{\mathrm{m} p \mathrm{~N}_{2}}\right]_{0}^{\vartheta_{3}} \vartheta_{3}}
$$

Where: $\lambda$ is the air excess ratio; $O_{\min }=2 \mathrm{kmol} / \mathrm{kmol}$, the minimal amount of oxygen in kilomol per kilomol of flue gases; $n_{\text {air_min }}=9,524 \mathrm{kmol} / \mathrm{kmol}$, the minimal amount 
of air; $n_{\mathrm{CO}_{2}}=1 \mathrm{kmol} / \mathrm{kmol}$, the amount of carbon dioxide; $n_{\mathrm{H}_{2} \mathrm{O}}=2 \mathrm{kmol} / \mathrm{kmol}$, the amount of water vapor; $H_{\mathrm{ml}}\left(0^{\circ} \mathrm{C}\right)=800800 \mathrm{~kJ} / \mathrm{kmol}$, the lower heating value of methane.

After excess air ratio is calculated, the amounts of the following substances can be solved:

$n_{\text {air }}=\lambda \cdot \frac{O_{\min }}{0,21}=\lambda \cdot \frac{2}{0,21}=9,524 \lambda \mathrm{kmol} / \mathrm{kmol}$,

$n_{\mathrm{O}_{2}}=(\lambda-1) \cdot O_{\min }=(\lambda-1) \cdot 2 \mathrm{kmol} / \mathrm{kmol}$,

$n_{\mathrm{N}_{2}}=0,79 \cdot n_{\text {air }}=7,524 \lambda \mathrm{kmol} / \mathrm{kmol}$,

$n_{\mathrm{fg}}=n_{\mathrm{CO}_{2}}+n_{\mathrm{H}_{2} \mathrm{O}}+n_{\mathrm{N}_{2}}+n_{\mathrm{O}_{2}} \mathrm{kmol} / \mathrm{kmol}$.

The values of mean molar heat capacities of the air and flue gases in the temperature range from $0^{\circ} \mathrm{C}$ to $\vartheta_{3}$ are determined from the analytical expressions given in [6].

\subsubsection{Thermal efficiency}

The thermal efficiency is defined by the expression

$$
\eta=\frac{w_{\text {net }}}{H_{\mathrm{ml}}\left(0{ }^{\mathrm{o}} \mathrm{C}\right)+n_{\text {air }}\left[C_{\mathrm{m} p, \text { air }}\right]_{\vartheta_{1}}^{\vartheta_{2}^{*}} \vartheta_{2}^{*}} .
$$

The algorithm for the computation of work output and thermal efficiency of the Brayton cycle with variable physical properties and variable composition of working substance is defined by the system of equations (1)-(10). It is evident that iterative procedure is needed. The work output and thermal efficiency are shown as functions of pressure ratio $r_{p}=p_{2} / p_{1}$ for given values of temperature ratio $r_{T}=T_{3} / T_{1}$, where in $T_{3}=1173,15 \mathrm{~K}, 1273,15 \mathrm{~K}$, $1373,15 \mathrm{~K}, 1473,15 \mathrm{~K}$ and $T_{1}=298,15 \mathrm{~K}$.

It is not possible to derive analytical expressions for maximum work output and maximum thermal efficiency, but from the results of the calculation according to the system of Eqs. (1) $\div(10)$ it is possible to determine an existence of maximum values, in given conditions.

\subsection{Exergy analysis of the Brayton cycle}

Many definitions for the exergy efficiency can be found in the literature. We use the definition according to which the exergy efficiency is equal to the ratio of work output and exergy of fuel.

Exergy balance of the whole cycle is represented by the following equation

$$
E x_{\text {fuel }}=W_{\text {net }}+E x_{\text {fg }}+\Delta E x
$$

Where: $E x_{\text {fuel }}$ is exergy of fuel; $E x_{\mathrm{fg}}$ is exergy of flue gases, $\Delta E x$ is exergy destruction. fuel

By dividing the above equation with the exergy of

$$
\frac{W_{\text {net }}}{E x_{\text {fuel }}}+\frac{E x_{\text {fg }}}{E x_{\text {fuel }}}+\frac{\Delta E x}{E x_{\text {fuel }}}=1
$$

the equation for the sum of exergy efficiencies is obtained

$$
\varepsilon_{\mathrm{p}}+\varepsilon_{\mathrm{fg}}+\varepsilon_{\Delta E x, \text { total }}=1
$$

Where: $\varepsilon_{\mathrm{p}}$ is the exergy efficiency which is the ratio of the work output of the cycle and the exergy of fuel; $\varepsilon_{\mathrm{fg}}$ is the exergy efficiency of flue gases; $\varepsilon_{\Delta E x \text {,total }}$ is the exergy efficiency which takes into account exergy destruction in all parts of the cycle: in combustion chamber, compressor and turbine.

\subsubsection{Exergy of fuel}

The fuel is in thermal $\left(T=T_{0}\right)$ and mechanical $(p=$ $p_{0}$ ) equilibrium with the environment, but it is not in the chemical equilibrium with the environment. The fuel at the ambient state has exergy because it is not in the global equilibrium with the environment, chemical reactions are possible. Chemical energy is released in the chemical reaction with oxygen from the ambient air, and it can be converted into work or into other energy form.

Expression for the exergy of methane at environment temperature and pressure is the following, [7]

$$
\begin{aligned}
& E x_{\text {fuel }}\left(p_{0}, T_{0}\right)=\Delta H_{\mathrm{mh}}\left(\mathrm{CH}_{4}\right)+ \\
& +T_{0}\left[S_{\mathrm{m}, \mathrm{CO}_{2}}\left(p_{0}, T_{0}\right)+2 S_{\mathrm{m}, \mathrm{H}_{2} \mathrm{O}}^{\mathrm{liq}}\left(p_{0}, T_{0}\right)-S_{\mathrm{m}, \mathrm{CH}_{4}}\left(p_{0}, T_{0}\right)-2 S_{\mathrm{m}, \mathrm{O}_{2}}\left(p_{0}, T_{0}\right)\right]+ \\
& +R_{\mathrm{m}} T_{0}\left[\ln \frac{p_{0}}{p_{\mathrm{CO}_{2}}^{\prime}}-2 \ln \frac{p_{0}}{p_{\mathrm{O}_{2}}^{\prime}}\right]
\end{aligned}
$$

Where: $\Delta H_{\mathrm{mh}}\left(\mathrm{CH}_{4}\right)=897797 \mathrm{~kJ} / \mathrm{kmol}$ is higher heating value of methane; $p_{\mathrm{CO}_{2}}^{\prime}=0,0003$ bar and $p_{\mathrm{O}_{2}}^{\prime}=$ 0,2056 bar are partial pressures of carbon dioxide and oxygen in air.

The absolute values of molar entropies of participants

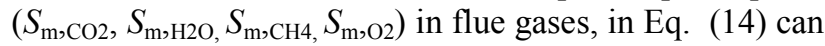
be found in [7].

Methane enters the combustion chamber at pressure $p_{2}=p_{2}^{*}$, so the expression for exergy of fuel is modified in the following way:

$$
E x_{\text {fuel }}\left(p_{2}, T_{0}\right)=E x_{\text {fuel }}\left(p_{0}, T_{0}\right)+R_{\mathrm{m}} T_{0} \ln \frac{p_{2}}{p_{0}}
$$

where $R_{\mathrm{m}}$ is the universal gas constant.

Since the pressure $p_{2}$ is variable ( $r_{p}$ is variable), the exergy of fuel is variable.

\subsubsection{Exergy efficiency $\varepsilon_{\mathrm{P}}$}

Exergy efficiency, defined as the ratio of work output and exergy of fuel, is often considered as exergy efficiency of the whole cycle 


$$
\varepsilon_{\mathrm{p}}=\frac{W_{\text {net }}}{E x_{\text {fuel }}\left(p_{2}, T_{0}\right)}
$$

and using Eqs. (6) and (11), it is

$$
\begin{aligned}
& \varepsilon_{\mathrm{p}}=\frac{T_{1} n_{\mathrm{fg}}\left[C_{\mathrm{m} p, \mathrm{fg}}\right]_{\vartheta_{4}^{*}}^{\vartheta_{3}} \eta_{\text {turb }} r_{T}\left(1-\left(\frac{1}{r_{p}}\right)^{\frac{\kappa_{\text {turb }}-1}{\kappa_{\text {turb }}}}\right)}{E x_{\text {fuel }}\left(p_{0}, T_{0}\right)+R_{\mathrm{m}} T_{0} \ln \left(r_{p}\right)}+ \\
& +\frac{T_{1} n_{\text {air }}\left[C_{\mathrm{m} p, \text { air }}\right]_{\vartheta_{1}}^{\vartheta_{2}^{*}} \frac{1-\left(r_{p}\right)^{\frac{\kappa_{\text {comp }}-1}{\kappa_{\text {comp }}}}}{\eta_{\text {comp }}}}{E x_{\text {fuel }}\left(p_{0}, T_{0}\right)+R_{\mathrm{m}} T_{0} \ln \left(r_{p}\right)}
\end{aligned}
$$

\subsubsection{Exergy efficiency of flue gases $\varepsilon_{\mathrm{fg}}$ at the turbine exit}

Flue gases leave the turbine at temperature $T_{4}^{*}$ and pressure $p_{0}$ and with the chemical composition different from the environment.

Exergy of flue gases is defined as follows:

$$
E x_{\mathrm{fg}}=n_{\mathrm{fg}}\left[\left[C_{\mathrm{m} p, \mathrm{fg}}\right]_{\vartheta_{0}}^{\vartheta_{4}^{*}}\left(\left(T_{4}^{*}-T_{0}\right)-T_{0} \ln \frac{T_{4}^{*}}{T_{0}}\right)+E x_{\mathrm{fg}, \mathrm{chem}}\right]
$$

where chemical exergy of flue gases is defined as

$$
E x_{\mathrm{fg}, \text { chem }}=T_{0}\left(y_{\mathrm{O}_{2}} \ln \frac{y_{\mathrm{O}_{2}}}{p_{\mathrm{O}_{2}}^{\prime}}+y_{\mathrm{N}_{2}} \ln \frac{y_{\mathrm{N}_{2}}}{p_{\mathrm{N}_{2}}^{\prime}}+y_{\mathrm{CO}_{2}} \ln \frac{y_{\mathrm{CO}_{2}}}{p_{\mathrm{CO}_{2}}^{\prime}}+y_{\mathrm{H}_{2} \mathrm{O}} \ln \frac{y_{\mathrm{H}_{2} \mathrm{O}}}{p_{\mathrm{H}_{2} \mathrm{O}}^{\prime}}\right)
$$

Where: $y_{\mathrm{O} 2}, y_{\mathrm{N} 2}, y_{\mathrm{CO} 2}, y_{\mathrm{H} 2 \mathrm{O}}$ are mole fractions of oxygen, nitrogen, carbon dioxide and vapour in flue gases. Partial pressures of participants in flue gases $\left(p_{\mathrm{O}_{2}}^{\prime}, p_{\mathrm{N}_{2}}^{\prime}, p_{\mathrm{CO}_{2}}^{\prime}\right.$, $\left.p_{\mathrm{H}_{2} \mathrm{O}}^{\prime}\right)$ can be found in [7].

The exergy efficiency of flue gases is obtained by dividing Eq. (18) with the exergy of fuel

$$
\varepsilon_{\mathrm{fg}}=\frac{E x_{\mathrm{fg}}}{E x_{\text {fuel }}}=\frac{n_{\mathrm{fg}}\left[\left|C_{\mathrm{mpfg}}\right|_{\vartheta_{0}}^{\vartheta_{4}^{*}}\left(\left(T_{4}^{*}-T_{0}\right)-T_{0} \ln \frac{T_{4}^{*}}{T_{0}}\right)+E x_{\mathrm{fg}, \text { chem }}\right]}{E x_{\text {fuel }}\left(p_{0}, T_{0}\right)+R_{\mathrm{m}} T_{0} \ln \left(r_{\mathrm{p}}\right)}
$$

\subsubsection{Exergy destruction in a combustion chamber, compressor and gas turbine}

Since a change of composition of working substance takes place in the combustion chamber, exergy destruction in the combustion chamber should be taken into account. It can be done using absolute entropy values of reactants (methane and air) and products of combustion (flue gases).
Exergy destruction in the combustion chamber is given in the following equation, [7]

$$
\Delta E x_{\mathrm{ch}}=T_{0}\left[n_{\mathrm{fg}} S_{\mathrm{m}, \mathrm{fg}}\left(T_{3}, p_{3}\right)-S_{\mathrm{m}, \mathrm{CH}_{4}}\left(T_{0}, p_{3}\right)-\lambda L_{\min } S_{\mathrm{m}, \text { air }}\left(T_{2}^{*}, p_{3}\right)\right]
$$

Where: $L_{\min }$ is the minimal amount of air for combustion, $n_{\mathrm{fg}}$ is the amount of vet flue gases, which can be calculated

$n_{\mathrm{fg}}=1+9,5238 \cdot \lambda$

$S_{\mathrm{m}, \mathrm{fg}}\left(T_{3}, p_{3}\right)$ is the absolute value of molar entropy of flue gases and can be calculated as follows

$$
S_{\mathrm{m}, \mathrm{fg}}\left(T_{3}, p_{3}\right)=\sum_{i} y_{i} S_{\mathrm{m} i}\left(T_{3}, p_{0}\right)-R_{\mathrm{m}}\left(\ln \frac{p_{3}}{p_{0}}+\sum_{i} y_{i} \ln y_{i}\right)
$$

where $y_{i}$ represents mole fractions of oxygen, nitrogen, carbon dioxide and vapour in flue gases

$y_{i}=n_{i} / n_{\mathrm{fg}}$

$S_{\mathrm{m} i}\left(T_{3}, p_{0}\right)$ represents absolute value of molar entropy of the participants in flue gases at temperature $T_{3}$ and pressure $p_{0}=101325 \mathrm{~Pa}$. The values of $S_{\mathrm{m} i}\left(T_{3}, p_{0}\right)$ are given in [7]. $R_{\mathrm{m}} \ln \left(p_{3} / p_{0}\right)$ represents the decrease of molar entropy of flue gases due to the increase of pressure; $R_{\mathrm{m}}$ $\sum_{i} y_{i} \ln y_{i}$ represents the increase of molar entropy of flue gases due to mixing; $S_{\mathrm{m}, \mathrm{CH}_{4}}\left(T_{0}, p_{3}\right)$ represents the molar entropy of methane which can be calculated using the following equation

$$
S_{\mathrm{m}, \mathrm{CH}_{4}}\left(T_{0}, p_{3}\right)=S_{\mathrm{m}, \mathrm{CH}_{4}}\left(T_{0}, p_{0}\right)-R_{\mathrm{m}} \ln \frac{p_{3}}{p_{0}}
$$

Where: $S_{{\mathrm{m}, \mathrm{CH}_{4}}_{4}}\left(T_{0}=298,15 \mathrm{~K}, p_{0}=101325 \mathrm{~Pa}\right)=186,16$ $\mathrm{kJ} /(\mathrm{kmol} \cdot \mathrm{K})$, according to [7].

Absolute value of molar entropy of air $S_{\mathrm{m} \text {,air }}\left(T_{2}^{*}, p_{3}\right)$, can be calculated using the following equation

$S_{\mathrm{m}, \text { air }}\left(T_{2}^{*}, p_{3}\right)=S_{\mathrm{m}, \text { air }}\left(T_{2}^{*}, p_{0}\right)-R_{\mathrm{m}} \ln \frac{p_{3}}{p_{0}}$

where $S_{\mathrm{m}, \text { air }}\left(T_{2}^{*}, p_{0}\right)$ is taken from [7].

Exergy destruction in the combustion chamber divided by the exergy of fuel gives the exergy efficiency defined by the following equation 
$\varepsilon_{\Delta E x, \mathrm{ch}}=\frac{T_{0}\left[n_{\mathrm{fg}} S_{\mathrm{m}, \mathrm{fg}}\left(T_{3}, p_{3}\right)-S_{\mathrm{m}, \mathrm{CH}_{4}}\left(T_{0}, p_{3}\right)-\lambda L_{\mathrm{min}} S_{\mathrm{m}, \mathrm{air}}\left(T_{2}^{*}, p_{3}\right)\right]}{E x_{\text {fuel }}\left(p_{0}, T_{0}\right)+R_{\mathrm{m}} T_{0} \ln \left(r_{\mathrm{p}}\right)}$

The exergy destruction in a compressor is caused by the nonisentropic compression process of air. The exergy destruction in compressor divided by the exergy of fuel gives the following exergy efficiency

$\varepsilon_{\Delta E x, \text { comp }}=\frac{T_{0} \cdot n_{\text {air }} \cdot\left(\left|C_{\text {mpair }}\right|_{\vartheta_{1}}^{\vartheta_{2}^{*}} \cdot \ln \left(\frac{T_{2}^{*}}{T_{1}}\right)-R_{\mathrm{m}} \ln \left(r_{\mathrm{p}}\right)\right)}{E x_{\text {fuel }}\left(p_{0}, T_{0}\right)+R_{\mathrm{m}} T_{0} \ln \left(r_{\mathrm{p}}\right)}$

The exergy destruction in gas turbine is caused by the nonisentropic expansion process of flue gases. The exergy destruction in gas turbine divided by the exergy of fuel gives the following exergy efficiency

$\varepsilon_{\Delta E x, \text { turb }}=\frac{T_{0} \cdot n_{\mathrm{fg}} \cdot\left(\left|C_{\mathrm{m} p \mathrm{fg}}\right|_{\vartheta_{3}}^{\vartheta_{4}^{*}} \cdot \ln \left(\frac{T_{4}^{*}}{T_{3}}\right)-R_{\mathrm{m}} \ln \left(\frac{1}{r_{\mathrm{p}}}\right)\right)}{E x_{\text {fuel }}\left(p_{0}, T_{0}\right)+R_{\mathrm{m}} T_{0} \ln \left(r_{\mathrm{p}}\right)}$

The total exergy destruction divided by the exergy of fuel is the sum of the exergy destructions in combustion chamber, turbine and compressor also divided by the exergy of fuel.

$\varepsilon_{\Delta E x, \text { total }}=\varepsilon_{\Delta E x, \mathrm{ch}}+\varepsilon_{\Delta E x, \mathrm{comp}}+\varepsilon_{\Delta E x, \text { turb }}$

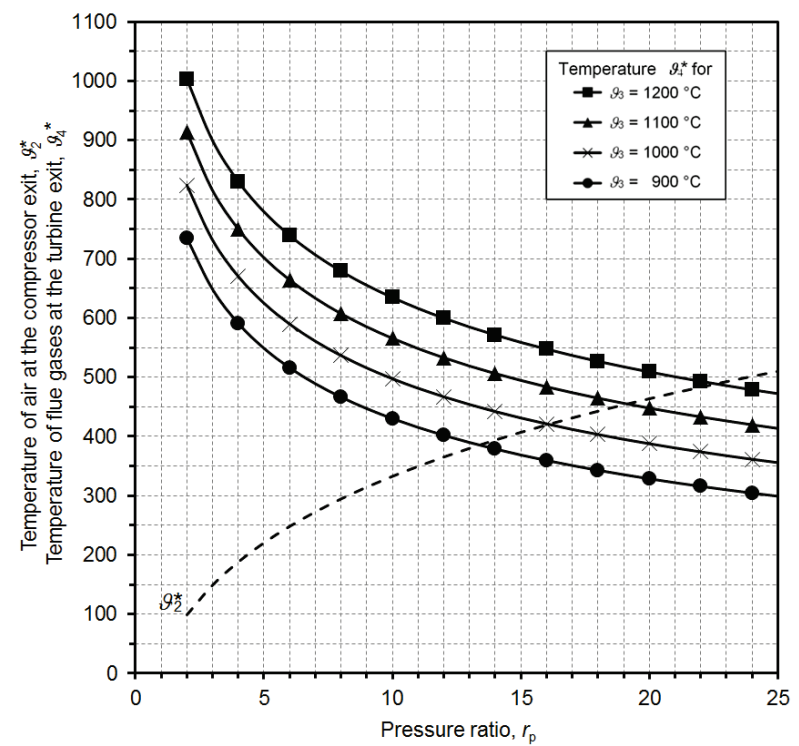

Figure 2a Temperature of air $\vartheta_{2}^{*}$ at the compressor exit, temperature of flue fases $\vartheta_{4}^{*}$ at the turbine exit, as functions of pressure ratio $r_{p}$ and temperature of flue gases $\vartheta_{3}$ at the turbine inlet

\section{Results of the calculation}

In the given model the variable physical properties and variable composition of working substances are considered, so first of all the temperatures of the working substances in the characteristic points of the process are calculated. The diagram in Fig. 2a shows the temperature of air $\vartheta_{2}^{*}$ at the compressor exit and the temperature of flue gases $\vartheta_{4}^{*}$ at the turbine exit as the functions of the pressure ratio $r_{p}$ and temperature of flue gases $\vartheta_{3}$ at the turbine inlet.

The diagram in figure $2 \mathrm{~b}$ shows the air excess ratio $\lambda$ as function of the pressure ratio $r_{p}$ and temperature of flue gases $\vartheta_{3}$ at the turbine inlet.

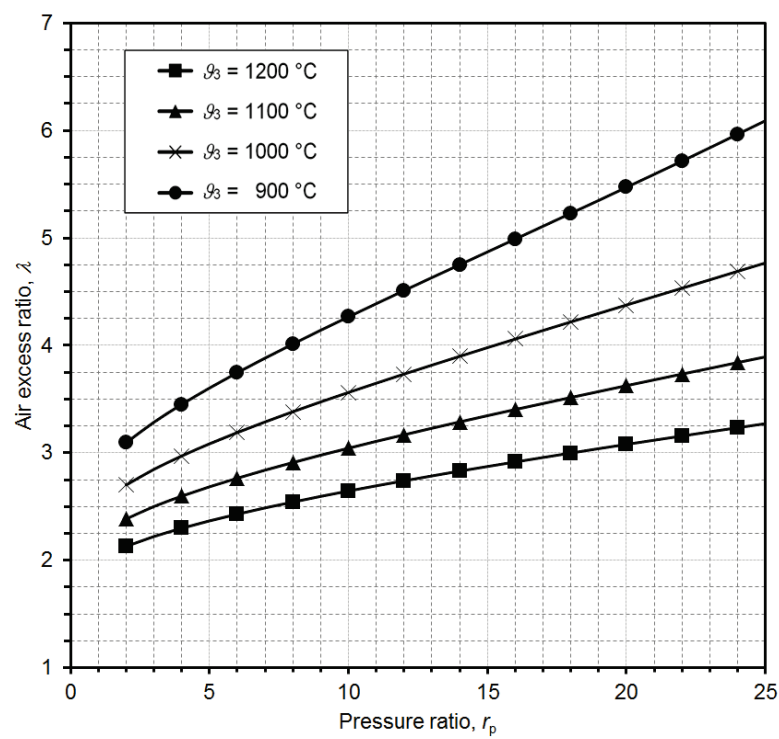

Figure 2b Air excess ratio $\lambda$ as function of the pressure ratio $r_{p}$ and temperature of flue gases $\vartheta_{3}$ at the turbine inlet

The temperature of air $\vartheta_{2}^{*}$ at the compressor exit is not dependent on the temperature of the flue gases, but it is dependent on the pressure ratio in a way that it increases with the increase of the pressure ratio. The pressure ratio is taken in the range from 2 to 25 and the highest value of the temperature $\vartheta_{2}^{*}$ is $510,1^{\circ} \mathrm{C}$.

The temperature of flue gases at the turbine exit depends on the pressure ratio $r_{p}$ and temperature ratio $r_{T}$. It decreases with the increase of pressure ratio and increases with the increase of the temperature ratio. The highest value of the temperature ratio is 4,94 , in the case in which the temperature of flue gases at the turbine inlet is $1200{ }^{\circ} \mathrm{C}$. Fig. $2 \mathrm{~b}$ shows that the air excess ratio increases with the increase of pressure ratio, and decreases with the increase of temperature ratio. The highest value of the air excess ratio is obtained for the $r_{T}$ $=3,94$ and it is 6,092 .

The dimensionless work output as function of the pressure ratio $r_{p}$ and temperature of flue gases $\vartheta_{3}$ at the turbine inlet is shown in Fig. 3.

In the present calculation the values of isentropic efficiencies of the compressor and turbine are 0,88 and 0,92 , respectively. The work output increases, reaches maximum and decreases with the increase of pressure ratio. It happens for each of the given values of temperature $\vartheta_{3}$. The pressure ratio in which the function reaches maximum moves to the higher value with the increase of temperature $\vartheta_{3}$. Comparing the results obtained in this model with the results of the air standard 
model of the Brayton cycle, given in [4], we can notice that the values of the optimal pressure ratio and maximal values of the work output obtained in the air standard model are higher than in this model and these differences increase with the increase of the temperature ratio.

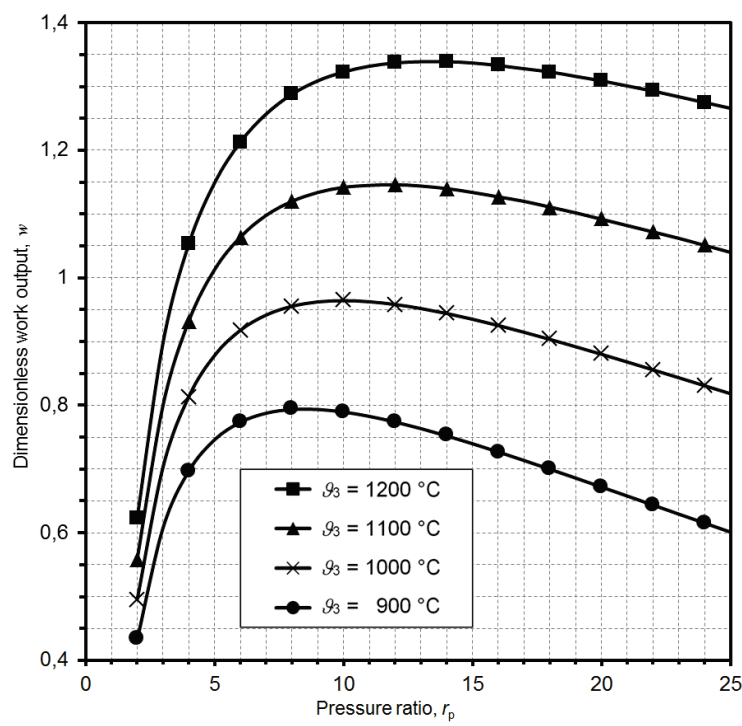

Figure 3 Dimensionless work output as function of the pressure ratio $r_{p}$ and temperature $\vartheta_{3}$ of flue gases

The diagram in Fig. 4 shows the thermal efficiency as function of the pressure ratio $r_{p}$ and temperature $\vartheta_{3}$ of flue gases.

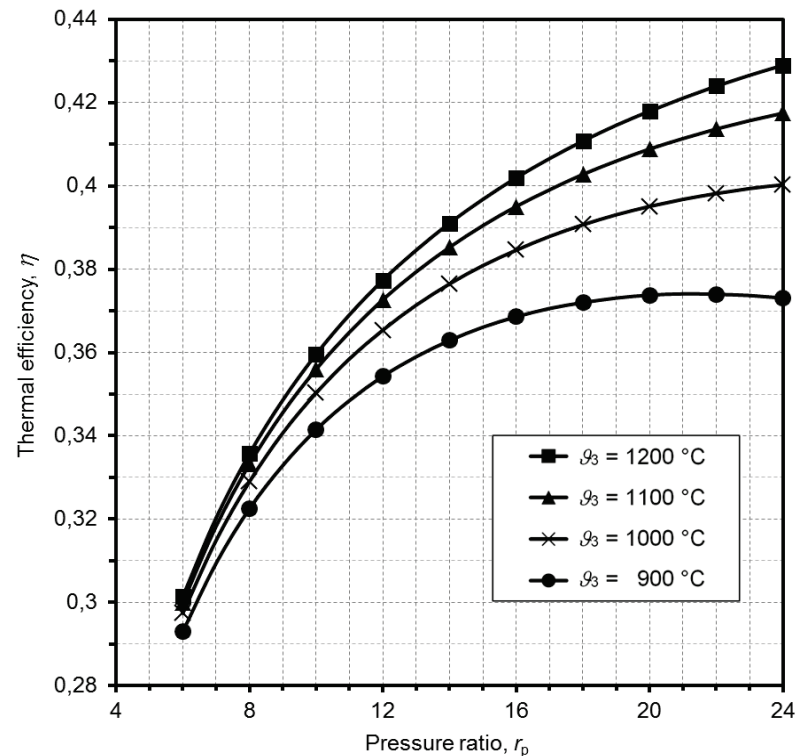

Figure 4 Thermal efficiency as function of the pressure ratio $r_{p}$ and temperature $\vartheta_{3}$ of flue gases

It can be seen that thermal efficiency increases with the increase of pressure ratio, but in the given range of the pressure ratio, the function has a maximum only for $\vartheta_{3}$ $=900{ }^{\circ} \mathrm{C}$. If this thermal efficiency is compared with the thermal efficiency of the air standard model, it can be noticed that the air standard model gives very similar values of the thermal efficiency.
As in the air standard model, also in this model the optimal value of pressure ratio in which thermal efficiency reaches maximum is different from the optimal value of pressure ratio in which work output reaches maximum.

The diagram in Fig. 5 shows dimensionless work output and thermal efficiency as functions of pressure ratio for temperature $\vartheta_{3}=900{ }^{\circ} \mathrm{C}$.



Figure 5 Design domain of the Brayton cycle for $\vartheta_{3}=900{ }^{\circ} \mathrm{C}$

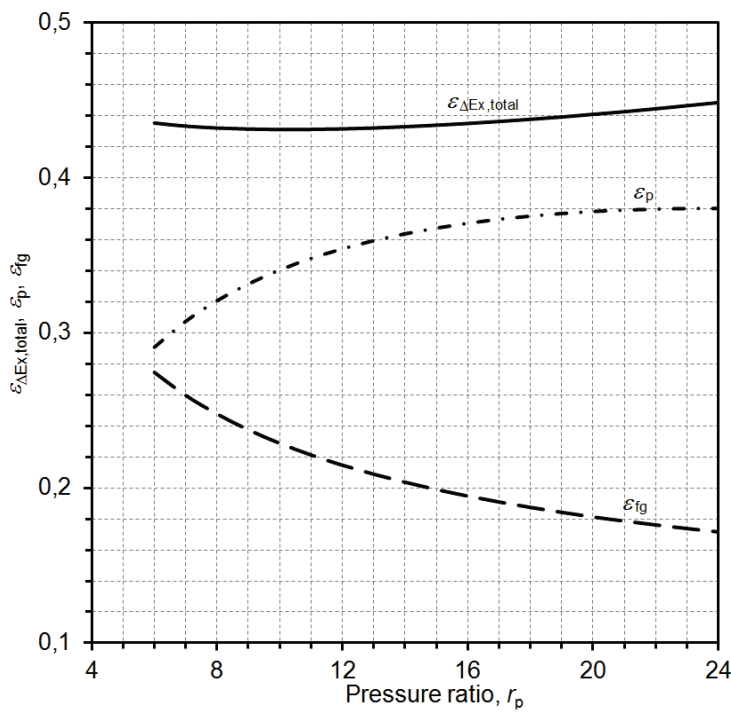

Figure 6 Exergy efficiencies of Brayton cycle as function of pressure ratio $r_{p}$ for $\vartheta_{3}=900{ }^{\circ} \mathrm{C}$

Criterion of the optimization of the Brayton cycle depends on the application of the cycle, like mentioned in the introduction. One acceptable goal function is that which is a compromise between maximum work output and maximum thermal efficiency. The goal function in the form $w / w_{\max }+\eta / \eta_{\max }$ defines $r_{p}$ for which the thermal efficiency would be a bit less than its maximum, but greater than the thermal efficiency at maximum work output, and the work output would be a bit less than its maximum but greater than the work output at maximum thermal efficiency, [8]. The design domain of the Brayton cycle lies in the interval limited by the values of optimal pressure ratio in which work output reaches maximum and in which thermal efficiency reaches maximum. For 
example, for $\vartheta_{3}=900{ }^{\circ} \mathrm{C}$, this domain is shown in the diagram in Fig. 5. It is interval 8,5 $\leq r_{p} \leq 21,1$.

The diagram in Fig. 6 shows curves of exergy efficiencies of the Brayton cycle as functions of pressure ratio for temperature of flue gases $\vartheta_{3}=900{ }^{\circ} \mathrm{C}$ at the turbine inlet.

The exergy efficiency defined as the ratio of the work output and exergy of fuel, which is often called the exergy efficiency of the cycle, [9], increases with the increase of pressure ratio and has a maximum at higher value of pressure ratio. For the temperature of flue gases $900{ }^{\circ} \mathrm{C}$ the maximum exergy efficiency is 0,374 at $r_{p}=21,2$. This point is close to the optimal pressure ratio obtained for the maximum thermal efficiency.

The exergy efficiency of flue gases defined as exergy of flue gases divided by the exergy of fuel significantly decreases with the increase of pressure ratio.

The diagram in Fig. 7 shows exergy efficiencies that takes into account exergy destructions in the combustion chamber, turbine and compressor as functions of pressure ratio.

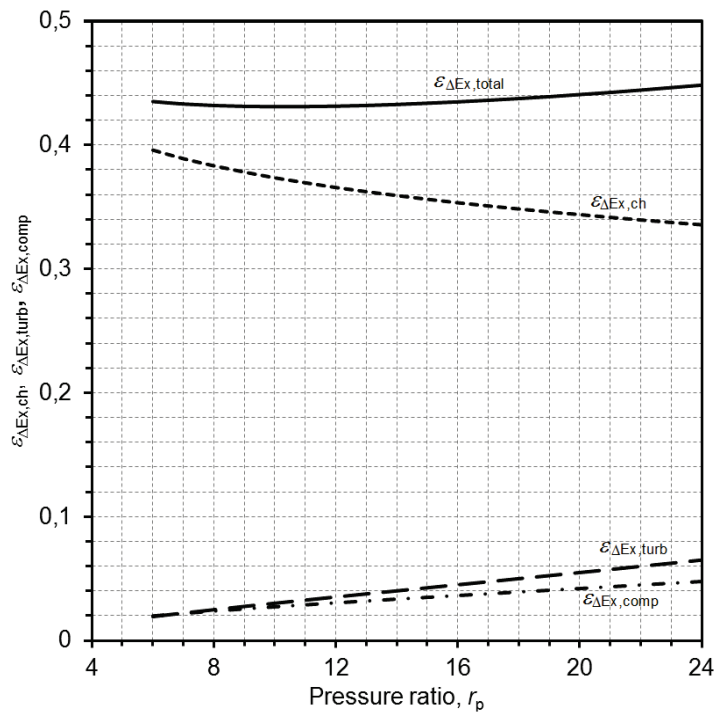

Figure 7 Exergy destructions (divided by the exergy of fuel) in combustion chamber, turbine and compressor as functions of pressure ratio for $\vartheta_{3}=900{ }^{\circ} \mathrm{C} ; \eta_{\text {comp }}=0,88 \mathrm{i} \eta_{\text {turb }}=0,92$

The exergy efficiency which takes into account the total exergy destruction of the cycle slightly increases with the increase of pressure ratio and its value is in the range $0,44 \div 0,45$ which means that $44 \div 45 \%$ of the exergy of fuel is lost in the combustion chamber, turbine and compressor. The exergy destruction in the combustion chamber is considerably higher than the exergy destructions in turbine and compressor and it decreases with the increase of pressure ratio, from the value 0,4 to 0,34 . The exergy destruction in the combustion chamber is a result of the chemical change, change of the composition and temperature of participants during combustion process. The exergy destructions in the turbine and compressor slightly increase with the increase of pressure ratio and they are results of the internal irreversible processes, compression of the air and expansion of the flue gases. The values of these destructions are determined by the values of the isentropic efficiencies in the compressor and turbine, 0,88 and 0,92, respectively.

\section{Conclusion}

The analysis of the Brayton cycle is performed using a model with variable physical properties and variable composition of working substance. This model better describes the process in the gas turbine engine than the air- standard model but it is not general. The model is valid for the fuel methane and for the given temperatures of the flue gases at the turbine inlet. The model is solved iteratively because molar heat capacities of the air and flue gases are functions of the temperature. The maximum work output and maximum thermal efficiency are obtained for the given values of the temperature of flue gases at the turbine inlet. The model with variable physical properties and variable composition of working substance gives lower values of work output than the air standard model and practically the same values of the thermal efficiency. In both models, the optimal pressure ratio in which thermal efficiency reaches maximum is higher than the optimal values of pressure ratio in which work output reaches maximum. The exergy analysis showed that the exergy destruction in the combustion chamber is significantly higher than the exergy destructions in the compressor and turbine.

\section{$5 \quad$ References}

[1] Polyzakis, A. L.; Koroneos, C.; Xydis, G. Optimum gas turbine cycle for combined cycle power plant. // Energy Convers Manage. 49, (2008), pp. 551-563. DOl: 10.1016/j.enconman.2007.08.002

[2] Najjar, Y. S. H.; Akyurt, M. Combined cycles with gas turbine engines. // Heat Recovery Systems \& CHP. 14, (1994), pp. 93-103. DOI: 10.1016/0890-4332(94)90001-9

[3] Durmayaz, A.; Sogut, O. S.; Sahin, B.; Yavuz, H. Optimization of thermal systems based on finite-time thermodynamics and thermoeconomics. // Progress in Energy and Combustion Science. 30, (2004), pp. 175-217. DOI: 10.1016/j.pecs.2003.10.003

[4] Živić, M.; Galović, A.; Virag, Z. Detailed Analysis of the Effect of the Turbine and Compressor Isentropic Efficiency on the Thermal and Exergy Efficiency of the Brayton Cycle. // Thermal Science. 18, 3(2014), pp. 843-852. DOI: 10.2298/TSCI1403843Z

[5] Haseli, Y. Optimization of a regenerative Brayton cycle by maximization of a newly defined second law efficiency. // Energy Convers Manage. 68, (2013), pp. 133-40. DOl: 10.1016/j.enconman.2012.12.033

[6] Galović, A.; Virag, Z.; Živić, M.; Holik, M. Exergetic efficiency of the complete combustion process of some of the hydrocarbons // Proceedings of the Int. conference GAS 2010 / Osijek, 2010, pp. 10-21.

[7] Baehr, D. H. Thermodynamik, Korrgierter Nachdruck der. 5. Auflage, Springer - Verlag, Berlin, 1984. DOl: 10.1007/978-3-662-10531-3

[8] Hernandez, A. C. et al. Power and efficiency in a regenerative gas-turbine cycle with multiple reheating and intercooling stages. // J Phys D Appl Phys. 29, (1996), pp. 1462-1468. DOI: 10.1088/0022-3727/29/6/008

[9] Kanoglu, M.; Cengel, Y. A.; Dincer I. Efficiency Evaluation of Energy Systems. Springer Briefs in Energy, Springer, New York, 2012. DOI: 10.1007/978-1-4614-2242-6 


\section{Authors' addresses}

Prof. dr. sc. Marija Živić

Josip Juraj Strossmayer University of Osijek,

Mechanical Engineering Faculty in Slavonski Brod,

Trg Ivane Brlić Mažuranić 2, 35000 Slavonski Brod, Croatia

E-mail: mzivic@sfsb.hr

Prof. dr. sc. Antun Galović

University of Zagreb, Faculty of Mechanical Engineering and

Naval Architecture

Ivana Lučića 5, 10000 Zagreb, Croatia

E-mail: agalovic@fsb.hr

Prof. dr. sc. Jurij Avsec

University of Maribor, Faculty of Energy Technology,

Hočevarjev trg 1, 8270 Krško, Slovenia

E-mail: jurij.avsec@um.si

Mario Holik, mag. ing. mech.

Josip Juraj Strossmayer University of Osijek,

Mechanical Engineering Faculty in Slavonski Brod,

Trg Ivane Brlić Mažuranić 2, 35000 Slavonski Brod, Croatia

E-mail:mholik@sfsb.hr 